\title{
Article \\ Selection and Verification of Appropriate Reference Genes for Expression Normalization in Cryptomeria fortunei under Abiotic Stress and Hormone Treatments
}

\author{
Yingting Zhang ${ }^{1,2,3} \mathbb{D}$, Lijuan Zhu ${ }^{1,2,3}$, Jinyu Xue ${ }^{1,2,3}$, Junjie Yang ${ }^{1,2,3} \mathbb{D}$, Hailiang Hu ${ }^{1,2,3}$, Jiebing Cui ${ }^{1,2,3}$ \\ and Jin $X u^{1,2,3, *(D)}$
}

1 Key Laboratory of Forest Genetics \& Biotechnology of Ministry of Education, Nanjing Forestry University, Nanjing 210037, China; ytzhang@njfu.edu.cn (Y.Z.); zhulijuanlucky@163.com (L.Z.); xjinyu@njfu.edu.cn (J.X.); yangj@@njfu.edu.cn (J.Y.); huhailiang@njfu.edu.cn (H.H.); cuijiebing@163.com (J.C.)

2 Co-Innovation Center for Sustainable Forestry in Southern China, Nanjing Forestry University, Nanjing 210037, China

3 College of Forestry, Nanjing Forestry University, Nanjing 210037, China

* Correspondence: xjinhsh@njfu.edu.cn; Tel.: +86-25-8542-7319

check for

updates

Citation: Zhang, Y.; Zhu, L.; Xue, J.; Yang, J.; Hu, H.; Cui, J.; Xu, J.

Selection and Verification of

Appropriate Reference Genes for

Expression Normalization in

Cryptomeria fortunei under Abiotic

Stress and Hormone Treatments.

Genes 2021, 12, 791. https:/ /doi.org/

10.3390/genes12060791

Academic Editor: Alberto Acquadro

Received: 28 April 2021

Accepted: 21 May 2021

Published: 21 May 2021

Publisher's Note: MDPI stays neutral with regard to jurisdictional claims in published maps and institutional affiliations.

Copyright: (C) 2021 by the authors. Licensee MDPI, Basel, Switzerland. This article is an open access article distributed under the terms and conditions of the Creative Commons Attribution (CC BY) license (https:// creativecommons.org/licenses/by/ $4.0 /)$.

\begin{abstract}
Cryptomeria fortunei has become one of the main timber afforestation species in subtropical high-altitude areas of China due to its fast growth, good material quality, and strong adaptability, showing broad application prospects. Quantitative real-time PCR (qRT-PCR) is the most accurate and widely used gene expression evaluation technique, and selecting appropriate reference genes (RGs) is essential for normalizing qRT-PCR results. However, suitable RGs for gene expression normalization in C. fortunei have not been reported. Here, we tested the expression stability for 12 RGs in C. fortunei under various experimental conditions (simulated abiotic stresses (cold, heat, drought, and salinity) and hormone treatments (methyl jasmonate, abscisic acid, salicylic acid, and gibberellin) and in different tissues (stems, tender needles, needles, cones, and seeds) using four algorithms (delta Ct, geNorm, NormFinder, and BestKeeper). Then, geometric mean rankings from these algorithms and the RefFinder program were used to comprehensively evaluate RG stability. The results indicated $C Y P$, actin, UBC, and $18 S$ as good choices for studying C. fortunei gene expression. qRT-PCR analysis of the expression patterns of three target genes (CAT and MAPK1/6) further verified that the selected RGs were suitable for gene expression normalization. This study provides an important basis for C. fortunei gene expression standardization and quantification.
\end{abstract}

Keywords: Cryptomeria fortunei; qRT-PCR; reference gene; abiotic stress; hormone treatments; different tissues

\section{Introduction}

Quantitative real-time PCR (qRT-PCR) has the characteristics of high sensitivity, high efficiency, and convenient operation and can be used to accurately analyze experimental results [1-4]. Currently, it is one of the most commonly used methods and the most important method for investigating gene expression. However, qRT-PCR results are affected by many variable factors, such as RNA template, reverse transcription efficiency, primer specificity, protocol variability, and data normalization and analysis method. The main problems caused by inconsistent data normalization and analysis are widely ignored [3]. Therefore, it is very important to compare the expression levels of all tested genes with the reference genes (RGs) to maximize the reproducibility of data analysis to obtain more accurate and reliable analysis data.

An increasing number of studies have now shown that the most commonly used RGs in plants, such as the glyceraldehyde-3-phosphate dehydrogenase (GAPDH), actin, 18S ribosomal RNA (18S rRNA), $\beta$-tubulin (TUB), and transcription elongation factor (EF1 $\alpha$ ) genes [5-8], show large differences in applicability $[9,10]$. For example, the expression patterns of $18 S$ 
are unstable during the development of Chinese cabbage (Brassica rapa) flower buds [7] and under abiotic stress in moss (Syntrichia caninervis) [11] but stable in different tissues and under different treatments in millet (Panicum miliaceum) [12]. Perfect RGs are supposed to be expressed stably and constitutively in different tissues, as well as under all physiological conditions; unfortunately, there are no genes that are absolutely stably expressed. More specifically, the so-called stable expression of any RG occurs only in specific tissues or under specific environmental conditions [13]. Therefore, it is necessary to test the expression stability of multiple candidate RGs in different tissues or under different environmental conditions before conducting qRT-PCR experiments. To date, there are many reports on the screening of plant RGs under various conditions, including under (a)biotic stress and during growth and development in different tissues and varieties [11,13-15]. For example, $\mathrm{Ni}$ et al. [1] studied cotton rose (Hibiscus hamabo) under abiotic stress and found that actin and ski-interacting protein (SKIP) can be considered the best RGs for the analysis of gene expression. However, suitable RGs that can be used for normalization of gene expression in Chinese cedar (Cryptomeria fortunei) have not been reported.

C. fortunei, belonging to Taxodiaceae, is a species that is endemic to China. It has become one of the main fast-growing timber afforestation species in subtropical highaltitude areas in China because of its fast growth, straight trunk, and good texture, with broad application prospects. Cryptomeria prefers a warm and humid climate, and its growth is often affected by adverse environmental conditions, such as low temperature, drought and acid stresses, and hormone treatments [16-18]. For example, low temperature $(4,0,-4$, $-8,-12,-16$, and $-20^{\circ} \mathrm{C}$ ) for 2,12 , or $24 \mathrm{~h}$ significantly decreased the chlorophyll (chl) content (chl a, chl b, and chl a $+\mathrm{b}$ ) and chl fluorescence parameters (such as maximum quantum yields of photosystem II $\left(F_{\mathrm{v}} / F_{\mathrm{m}}\right)$ ), increased electrolyte leakage, and damaged needle chloroplast ultrastructure of $C$. fortunei, affecting its growth [17]. Li et al. treated C. japonica with different low temperatures $\left(0,-5,-10\right.$, and $\left.-15^{\circ} \mathrm{C}\right)$ for $12 \mathrm{~h}$, and also found that the electrolyte leakage and malondialdehyde (MDA) of the needles gradually increased with the decrease of the treatment temperature, while the free proline (Pro) and the content of soluble sugars increased first and then decreased with the decrease of the treatment temperature [19]. It can be seen that plant cell membrane permeability increases, intracellular electrolytes extravasate, and osmotic adjustment substances increase under low temperature, which prevents damage to cell structure and enhances protection. Futamura et al. [20] isolated three thaumatin-like protein (TLP)-encoding cDNAs (Cryj 3.1, 3.4 and 3.5) from the pollen of $C$. japonica. Then, one-month-old $C$. japonica seedlings were treated with an aqueous solution of $200 \mathrm{mM} \mathrm{NaCl}$ or plant hormones (salicylic acid (SA) and abscisic acid (ABA)) for $24 \mathrm{~h}$, and it was found that salt stress induced expression of Cryj 3.1 and Cryj 3.4, SA induced expression of Cryj 3.4, and ABA weakly induced expression of Cryj 3.5, indicating that various treatments can also promote allergen effects [20]. Although most studies on the effects of stress focus on morphology and physiology [16,17], some molecular studies of $C$. fortunei have also been reported, and they have all focused on the identification of differentially expressed genes and on the functional verification of genes [21,22]. Among the results, the gene expression profile is extremely important, and in gene expression analysis, the most commonly used internal RGs can no longer meet the requirements of accurate quantification. Therefore, it is necessary to study the internal RGs of $C$. fortunei.

We selected 12 candidate RGs, namely, 18S, actin, cyclophilin (CYP), histone H4 (HIS4), heat shock protein 70 (HSP70), serine/threonine-protein kinase (PBL), phosphoglycerate kinase 1 (PGK1), protein phosphatase 2A (PP2A), large subunit of the ribulose-1,5-bisphosphate carboxylase/oxygenase ( $r b c l), 60 S$ ribosomal protein L2 (RPL2), tubulin $\alpha-2$ (TUA2), and ubiquitinconjugating enzyme $(U B C)$, and systematically studied and analyzed the expression stability of these genes under abiotic stress (including low/high temperature, drought, and salinity) and various hormone treatments (methyl jasmonate (MeJA), ABA, SA, and gibberellin $\left(\mathrm{GA}_{3}\right)$ ), as well as in different tissues (stems, tender needles, needles, cones, and seeds), using four algorithms (delta Ct, geNorm, NormFinder, and BestKeeper) by qRT-PCR analy- 
sis. Then, the geometric mean of rankings among these four algorithms and the RefFinder network program were used to comprehensively and accurately determine the most stable RGs of $C$. fortunei. In addition, the most stable and unstable genes were used to normalize the expression levels of the three target genes, namely, catalase (CAT) and mitogen-activated protein kinase 1/6 (MAPK1/6), to verify the availability of the selected RGs in different tissues or under each treatment. These results identified appropriate RGs, which can be used to normalize the expression of genes in C. fortunei, providing a basis for normalizing gene expression in other coniferous species.

\section{Materials and Methods}

\subsection{Plant Materials and Treatments}

C. fortunei trees from Dagangshan, Jiangxi Province, China, exhibiting good growth with no disease or insect pests, were selected as the mother trees. In June 2019, semilignified branches with 2-3 lateral buds were cut as cuttings $(12-16 \mathrm{~cm})$. These cuttings with flat cuts on the top and $45^{\circ}$ oblique cuts on the bottom were soaked in distilled water for $12 \mathrm{~h}$, followed by rinsing with distilled water 3 times after surface sterilization with $1 \%(m / v)$ calcium hypochlorite $\left(\mathrm{Ca}(\mathrm{ClO})_{2}\right)$ for $10 \mathrm{~min}$ and then by soaking with $0.1 \mathrm{~g} \mathrm{~L}^{-1}$ GGR rooting powder (Beijing Aibiti Biological Technology Co., Ltd., Beijing, China) for $4 \mathrm{~h}$. The treated C. fortunei cuttings were placed in round plastic planting pots $(15 \mathrm{~cm}$ in diameter and $15 \mathrm{~cm}$ height) with mixed soil substrate (peat:perlite:vermiculite:yellow sand, $1 / 1 / 1 / 1, v / v / v / v)$. These cutting seedlings were placed in the greenhouse of the Baima Teaching and Research Base of Nanjing Forestry University ( $31^{\circ} 37^{\prime}$ N, $119^{\circ} 11^{\prime}$ E), Nanjing, Jiangsu Province, China, with a 12/12-h photoperiod (day/night).

In September 2020, 123 C. fortunei plants with similar growth states were selected for 8 stress experiments. For abiotic stress, the $C$. fortunei cutting seedlings were exposed to 4 and $42{ }^{\circ} \mathrm{C}$ to simulate low- and high-temperature stresses, respectively; the plants were treated with $15 \%(\mathrm{~m} / \mathrm{v})$ polyethylene glycol (PEG)-6000 and $200 \mathrm{mM}$ sodium chloride $(\mathrm{NaCl})$ in 1/4-strength Hoagland solution $(200 \mathrm{~mL}$ per plant) to simulate drought and salt stress, respectively [1,4]. For hormone treatments, the plants were sprayed evenly with $200 \mu \mathrm{M}$ SA, $200 \mu \mathrm{M}$ MeJA, $200 \mu \mathrm{M}$ ABA, and $200 \mu \mathrm{M} \mathrm{GA}_{3}$ until all needles were completely moistened (150 mL per plant) [1,4]. The plants, except for those under low- or high-temperature stress, were cultivated at $25^{\circ} \mathrm{C}$, and all plants were cultivated in a light incubator (MLR 351H, Sanyo Electric Co., Ltd., Osaka, Japan) with the same photoperiod (12-h light/12-h dark cycle) and $60 \%$ relative humidity. Three biological replicates were performed for each treatment at each treatment timepoint $(5 \times 3$ plants), and samples were taken at $0,2,6,12,24$, and $48 \mathrm{~h}$ under each prolonged stress treatment [1]. Different tissue samples (stems, tender needles, needles, cones, and seeds) were collected from $C$. fortunei plants grown in a natural environment for 15 years. After the samples were collected, they were quickly frozen in liquid nitrogen and then stored at $-80^{\circ} \mathrm{C}$ until RNA extraction.

\subsection{RNA Extraction and $c D N A$ Preparation}

Total RNA was extracted from the samples $(0.1 \mathrm{~g})$ using an RNAprep Pure Plant Kit (Polysaccharides/Polyphenolics-Rich) (Bioteke Co., Beijing, China) according to the manufacturer's instructions. The RNA concentration and integrity were measured with a spectrophotometer (NanoDrop 2000, Thermo Scientific, Wilmington, DE, USA) and 1\% $(w / v)$ agarose gel electrophoresis, respectively. After quality verification, $0.8 \mu \mathrm{g}$ of each total RNA sample were reverse transcribed with the HiScript III RT SuperMix Kit (Vazyme Biotech Co., Ltd., Nanjing, Jiangsu, China) according to the manufacturer's protocol and then stored in a freezer at $-20^{\circ} \mathrm{C}$ until further use.

\subsection{Selection of Candidate RGs and Primer Design}

The transcriptome database of $C$. fortunei needles in our laboratory was configured into the local database of BioEdit software (Micro Focus International Ltd., Rockville, England) [23]. The unigene sequences in the transcriptome data were compared according 
to the commonly used internal RG sequences in previous reports, and 12 unigenes with high similarity and consistent annotation information in the local C. fortunei database were selected. BLASTX was performed against the NCBI non-redundant (NR) database to conduct online analysis of the conserved domains and open reading frames (ORFs) of the genes, and Primer Premier 5.0 software (Premier Biosoft International, Palo Alto, CA, USA) was used to design the RG primers based on these coding sequences (CDSs). The parameters were set as follows: PCR product length was 70-250 bp, dissolution temperature was $58-62{ }^{\circ} \mathrm{C}$, and GC content was $40-60 \%$. Then, we used NCBI PrimerBLAST (http:/ / www.ncbi.nlm.nih.gov/tools/primer-blast/, accessed on 7 September 2012) for the specific detection of plant primers. Finally, we identified 12 genes as candidate RGs, and all primers (Table 1) were synthesized by Tsingke Biotech Co., Ltd. (Nanjing, Jiangsu Province, China).

Table 1. Twelve candidate reference genes and primer sequences used in this study.

\begin{tabular}{|c|c|c|c|c|c|}
\hline $\begin{array}{l}\text { Gene } \\
\text { Symbol }\end{array}$ & Gene Name & Primer Sequence $\left(5^{\prime}\right.$ to $\left.3^{\prime}\right)$ & $\begin{array}{l}\text { Amplicon } \\
\text { Size (bp) }\end{array}$ & $\begin{array}{l}\text { PCR } \\
\text { Efficiency } \\
(\mathrm{E} \%)\end{array}$ & $\mathbf{R}^{2}$ \\
\hline $18 S$ & 18S ribosomal RNA & $\begin{array}{l}\text { TCTGGTCCTGTTCCGTTGG } \\
\text { GCTTTCGCAGTGGTTCGTC }\end{array}$ & 124 & 100.21 & 0.983 \\
\hline$A C T$ & actin & $\begin{array}{c}\text { GTTGCCATTCAAGCCGTTCT } \\
\text { AACAATTTCACGCTCAGCAGTAG }\end{array}$ & 228 & 98.54 & 0.984 \\
\hline$C Y P$ & cyclophilin & $\begin{array}{c}\text { TCTCGGGCAGCATTTCACGC } \\
\text { AGCCGAAACTGGCGCCAACA }\end{array}$ & 79 & 105.98 & 0.990 \\
\hline HIS4 & histone $\mathrm{H} 4$ & $\begin{array}{l}\text { TTCCAGTTGGAAGGAAAAATGTCTG } \\
\text { GGCGAGCGTGCTCAGTGTAT }\end{array}$ & 253 & 107.83 & 0.981 \\
\hline HSP70 & heat shock protein 70 & $\begin{array}{l}\text { AACGCAAGGGCTTTGAGAA } \\
\text { ACCTGGCACGGGTTATGGT }\end{array}$ & 139 & 103.40 & 0.980 \\
\hline$P B L$ & serine/threonine-protein kinase & $\begin{array}{l}\text { AGTTCTGCCATGGCCCGTGA } \\
\text { TGCAGTGCCAACAACCGCTG }\end{array}$ & 223 & 109.08 & 0.994 \\
\hline PGK1 & phosphoglycerate kinase 1 & $\begin{array}{l}\text { GCGGGCGAGTAAAGTGGTA } \\
\text { GGAGATCAAATACTTAATGGTGGGT }\end{array}$ & 181 & 95.14 & 0.990 \\
\hline$P P 2 A$ & protein phosphatase $2 \mathrm{~A}$ & $\begin{array}{l}\text { TGAAGGAGGGAGATTTGATTGA } \\
\text { CAGTTCCGATGCACTTGGGT }\end{array}$ & 128 & 107.83 & 0.988 \\
\hline$r b c l$ & $\begin{array}{l}\text { large subunit of the } \\
\text { ribulose-1,5-bisphosphate }\end{array}$ & CGTATTACAGTTCGGTGGAGGG & 185 & 101.39 & 0.997 \\
\hline RPL2 & $\begin{array}{l}\text { carboxylase/oxygenase } \\
60 \mathrm{~S} \text { ribosomal protein L2 }\end{array}$ & $\begin{array}{c}\text { CACAAGCGGCAGCTAGTTCA } \\
\text { CCAGCATCGTTGTGGGAAAG } \\
\text { GTGACCTCCTCCTCTATGTCGTAT }\end{array}$ & 70 & 102.28 & 0.980 \\
\hline TUA2 & tubulin $\alpha-2$ & $\begin{array}{l}\text { CTTTCCTCGCACTCGCTGTT } \\
\text { GGTGTAGGTAGGGCGGTCAA }\end{array}$ & 181 & 109.94 & 0.992 \\
\hline$U B C$ & ubiquitin-conjugating enzyme & $\begin{array}{l}\text { CTCGCAGAATCATAAAGGAAACAC } \\
\text { CCATTGGATACTCTTCAGGCAAA }\end{array}$ & 180 & 107.09 & 0.981 \\
\hline
\end{tabular}

$\mathrm{R}^{2}$, correlation coefficient.

\subsection{RT-PCR and $q R T-P C R$ Analysis}

RT-PCR amplification was performed using the Fast PCR Kit (Vazyme Biotechnology Co., Ltd., Nanjing, Jiangsu Province, China) and the reaction system was set as follows: $2 \mu \mathrm{L}$ of each primer pair (10 $\mu \mathrm{M}$ forward and reverse primers), $1 \mu \mathrm{L}$ of cDNA, $10 \mu \mathrm{L}$ of $2 \times$ Rapid Taq Master Mix, and $7 \mu \mathrm{L}$ of $\mathrm{ddH}_{2} \mathrm{O}$. The amplification program was set as follows: $95^{\circ} \mathrm{C}$ for $3 \mathrm{~min}$, followed by 40 cycles of $95^{\circ} \mathrm{C}$ for $15 \mathrm{~s}, 60^{\circ} \mathrm{C}$ for $15 \mathrm{~s}$ and $72{ }^{\circ} \mathrm{C}$ for $15 \mathrm{~s}$, and finally extension at $72{ }^{\circ} \mathrm{C}$ for $5 \mathrm{~min}$. The accuracy of the designed primers was verified by $2.5 \%(w / v)$ agarose gel electrophoresis after PCR.

Two microliters of each cDNA template for all samples were mixed evenly, and the cDNA was serially diluted (1:4, 1:24, 1:124, 1:624, 1:3124, 1:15624; cDNA:water, $v: v)$. The $\mathrm{Ct}$ value at each concentration was determined to establish a standard curve, and the correlation coefficient $\left(\mathrm{R}^{2}\right)$ and PCR efficiency $(\mathrm{E} \%)$ were calculated [24].

All qRT-PCRs were carried out by using the ChamQTM SYBR ${ }^{\circledR}$ qPCR Master Mix Kit (Low ROX Premixed) (Vazyme Biotechnology Co., Nanjing, China), and the reaction system $(20 \mu \mathrm{L})$ was as follows: $10 \mu \mathrm{L}$ of $2 \times$ ChamQ SYBR qPCR Master Mix (Low ROX Premixed); $2 \mu \mathrm{L}$ of 5-fold-diluted cDNA (cDNA:water, 1:4, v:v); $0.8 \mu \mathrm{L}$ of each specific primer pair (10 $\mu \mathrm{M}$ forward and reverse primers); and $7.2 \mu \mathrm{L}$ of $\mathrm{ddH}_{2} \mathrm{O}$. In addition, for each gene, a non-template control was included. qRT-PCR was performed on an Applied Biosystems (ABI) 7500 fast real-time PCR system (ABI, Foster City, CA, USA) for amplification, and the 
procedure was as follows: $30 \mathrm{~s}$ at $95^{\circ} \mathrm{C}$, followed by 40 cycles of $95^{\circ} \mathrm{C}$ for $10 \mathrm{~s}$, and $60{ }^{\circ} \mathrm{C}$ for $30 \mathrm{~s}$; then a melting curve was generated at $60-95^{\circ} \mathrm{C}$ immediately after completion of the qRT-PCR to detect primer dimerization and other artefacts of amplification. Each reaction had three biological replicates and three technical replicates.

\subsection{Gene Expression Stability Analysis}

Four different algorithms, i.e., delta Ct [25], geNorm (version 3.5) [26], NormFinder (version 0.953) [27], and BestKeeper (version 1.0) [28], were used to carry out statistical analysis on the stability of the expression of RGs in different samples. For geNorm and NormFinder, the original $\mathrm{Ct}$ value was converted to $2^{-\Delta \mathrm{Ct}}$ (delta $\mathrm{Ct}=$ original $\mathrm{Ct}$ value lowest $\mathrm{Ct}$ value in each group) and then used for the stability analysis of RGs, while for BestKeeper, the E value calculated by the LinRegPCR program based on the original $\mathrm{Ct}$ value and the original $\mathrm{Ct}$ value were used to calculate the coefficient of variation $(\mathrm{CV})$ and standard deviation (SD) of the candidate RG expressions. In addition, geNorm can also determine the appropriate internal RG number by calculating the paired difference value $\mathrm{V}_{\mathrm{n}} / \mathrm{V}_{\mathrm{n}+1}$ of two consecutive normalization factors.

The geometric mean was the average of the rankings of genes in the four algorithms (delta Ct, geNorm, NormFinder, and BestKeeper) under each treatment, in different tissues or across all samples. At the same time, RefFinder analysis (https:/ /www.heartcure.com. $\mathrm{au} /$ reffinder/, accessed on 31 January 2012) was also used to comprehensively verify results of RG stability analysis.

\subsection{Validation of RGs by $q R T-P C R$}

To examine the reliability of the selected RGs, the optimal RGs and the least stable RGs were used to normalize the expression levels of three target genes (CAT, MAPK1, and $M A P K 6)$ using the $2^{-\triangle \Delta \mathrm{Ct}}$ method [29] under each experimental condition. Primer pairs for amplification of CAT (forward: $5^{\prime}$-TGATGTGGGTATCCCGTTGA-3' and reverse: $5^{\prime}$ GGTTGCGTGACTATGATTCGTT-3'), MAPK1 (forward: 5'-TTGATGACCAAATATGGGACG$3^{\prime}$ and reverse: $5^{\prime}-\mathrm{CAACGGTTTGCATTGTTGC}-3^{\prime}$ ), and MAPK6 (forward: $5^{\prime}$-GAGGC TGATCTTGGATTTGTTC $-3^{\prime}$ and reverse: $5^{\prime}$-CAGGCTGGCTCATCACTCAC $-3^{\prime}$ ) were designed.

\section{Results}

\subsection{Assessment of Primer Specificity and PCR Efficiency}

A total of 12 candidate RGs were selected for gene normalization studies (Table 1). To determine the primer specificity of each primer, $2.5 \%(w / v)$ agarose gel electrophoresis and melting curve analysis were performed, and the results showed that we obtained specific target fragments with the expected lengths and sequences of these genes (Supplementary Figure S1). The qRT-PCR efficiency ranged from $95.14 \%$ to $109.94 \%$, and the $R^{2}$ of all primer pairs ranged from 0.980 to 0.997 (Table 1). These results showed that all 12 pairs of primers met the requirements of qRT-PCR and could be used in further analysis.

\subsection{Expression Profiles of Candidate RGs}

To investigate the applicability of 12 candidate genes, we analyzed the expression levels (Ct values) of these RGs in all 159 samples (including under abiotic stress (heat, cold, drought, and salinity), under hormone treatments (ABA, SA, MeJA, and $\mathrm{GA}_{3}$ ) and in different tissues (stem, seeds, cone, leaves, and tender leaves)) by qRT-PCR analysis. These average Ct values varied from 6.241 (for 18S) to 26.958 (for CYP), among which $18 S$ and $r b c l$ had relatively low $\mathrm{Ct}$ values, indicating that they had a high initial copy number in the samples and greater expression levels, whereas HIS4, PP2A, PBL, and CYP had the lowest expression levels (Figure 1). Moreover, the $18 \mathrm{~S}$ expression levels were the least variable ( $3.011 \mathrm{Ct}$, the maximum and minimum $\mathrm{Ct}$ values were 7.629 and 4.619, respectively) among all samples, followed by PBL $(3.610 \mathrm{Ct})$, whereas the TUA2 expression levels showed the 
greatest variability ( $8.787 \mathrm{Ct}$, ranging from 19.601 to 28.388) (Figure 1). Apparently, $18 \mathrm{~S}$ and PBL can be used as two stable RGs, but further analysis of these genes is needed.

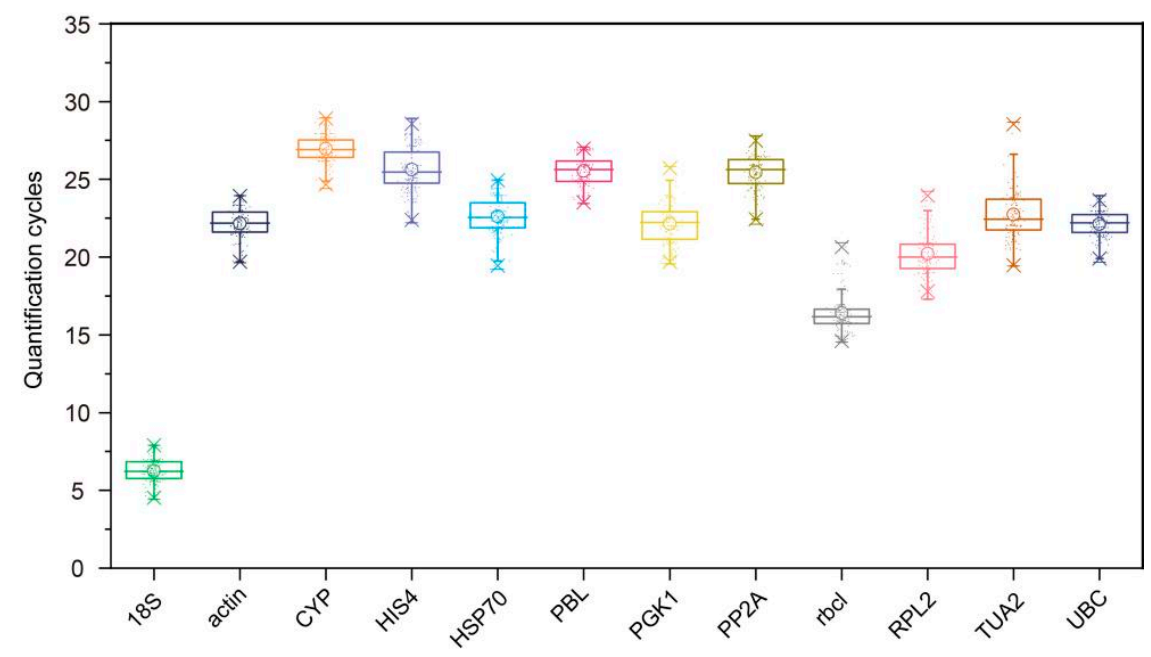

Figure 1. Quantification cycle values of 12 candidate reference genes in 159 samples. The boxes indicate the 25th and 75th percentiles, with the lines in the center of the boxes representing the medians. The whiskers and asterisks represent the $99 \%$ confidence intervals and outliers, respectively. The upper and lower horizontal lines indicate the maximum and minimum values, respectively, and the small circles represent the average values.

\subsection{Expression Stability of Candidate RGs}

Four different algorithms, including delta $\mathrm{Ct}$, geNorm, NormFinder, and BestKeeper, were used to estimate the expression stability of the candidate RGs under various experimental conditions.

\subsubsection{Delta Ct Analysis}

The delta Ct method is used to compare the relative expression levels of "gene pairs" in groups of samples and ranks the stability of candidate RGs based on the reproducibility of the average standard deviation (STDEV) of gene expression differences between samples [25]. The lower the STDEV value is, the more stable the gene. As shown in Figure 2, under cold stress, actin and $r b c l$ had the smallest STDEVs of 0.81 and 0.82 , respectively, and were the most stable genes (Figure $2 \mathrm{a}$ ), whereas in heat-, $\mathrm{GA}_{3}{ }^{-}$, or MeJA-treated samples, $C Y P$ and $U B C$ were the most stable genes (Figure $2 \mathrm{~b}, \mathrm{f}, \mathrm{g}$ ). Under the drought and salt treatments, CYP and HSP70, and rbcl and $18 S$ were the two most stable RGs (Figure 2c,d). In tissues, $P B L$ and actin showed the highest stability (Figure 2i). In addition, under ABA treatment, SA treatment, abiotic stress, hormone treatments, and all sample conditions, CYP and actin all showed high stability (Figure 2e,h,j-l). In contrast, the statistical results for the last three rankings in each treatment/tissue showed that TUA2 (12 times, 100.00\%), PGK1 (9 times, $75.00 \%$ ) and HIS4 (7 times, 58.33\%) were the most unstable under most conditions (Figure 2). 

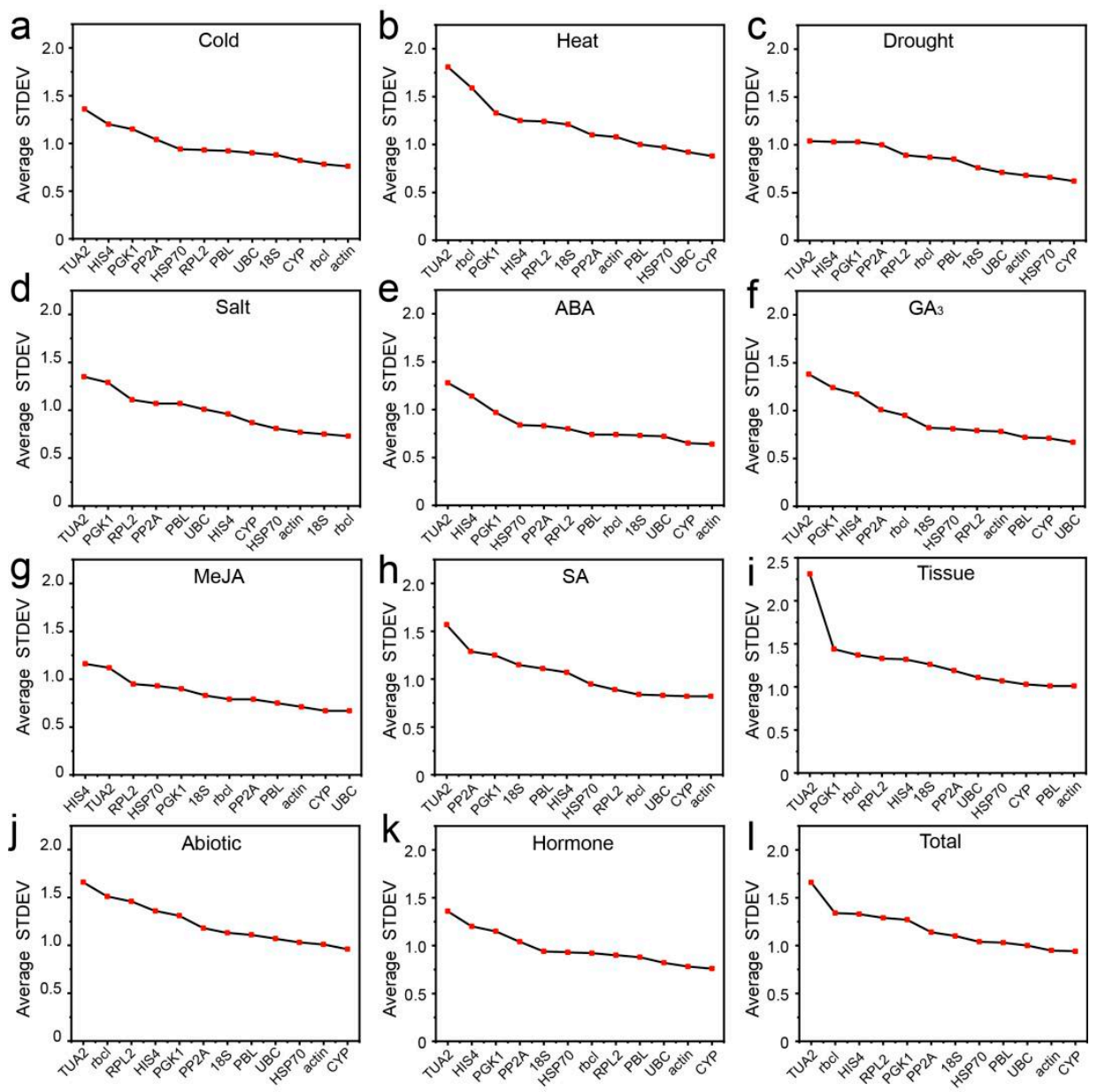

Figure 2. Average standard deviation (STDEV) indicated by delta Ct analysis. (a) $4{ }^{\circ} \mathrm{C}$ cold stress; (b) $42{ }^{\circ} \mathrm{C}$ heat stress; (c) drought stress simulated by 15\% PEG-6000 treatment; (d) salt stress stimulated by $200 \mathrm{mM} \mathrm{NaCl}$ treatment; (e) $200 \mu \mathrm{M}$ ABA treatment; (f) $200 \mu \mathrm{M} \mathrm{GA}_{3}$ treatment; (g) $200 \mu \mathrm{M} \mathrm{MeJA}$ treatment; (h) $200 \mu \mathrm{M}$ SA treatment; (i) in different tissues (stems, tender needles, needles, cones, and seeds); (j) under abiotic stress; (k) under hormone treatments; and (1) in total samples.

\subsubsection{GeNorm Analysis}

GeNorm software can calculate the stability (M value) of each $R G$ to evaluate stability and 1.5 is the default threshold of $\mathrm{M}$; the smaller the $\mathrm{M}$ value is, the better the stability of the RG [26]. For all samples, under all hormone treatments or under abiotic stress, UBC and actin were the most stable genes; for each treatment, there were significant differences in the expression stability of the 12 genes (Figure 3a). More specifically, $r b c l$ and $C Y P$ were the most stably expressed genes under cold stress; under drought stress simulated by PEG treatment or in various tissues, the most stable genes with standardized data were $C Y P$ and HSP70; and the samples treated with $\mathrm{NaCl}, r b c l$, and $18 S$ had higher expression stability than the other genes. For ABA-treated samples, $C Y P$ and actin were more stable than the other genes, and $U B C$ and $18 S$ showed the strongest stability under MeJA treatment. $U B C$ and $C Y P$ showed the most stable expression levels under SA treatment, $\mathrm{GA}_{3}$ treatment, or for samples treated at $42{ }^{\circ} \mathrm{C}$. In most cases, TUA2, PGK1, and HIS4 were generally the least stable RGs (Figure 3a). 
a
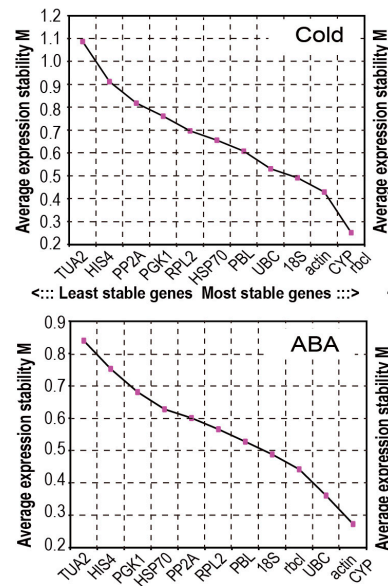

$<::$ Least stable genes Most stable genes ::

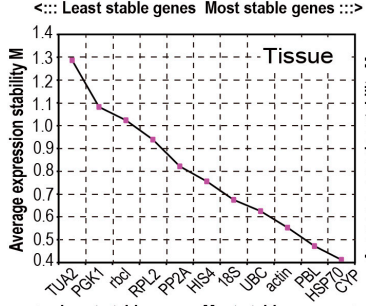

(b)

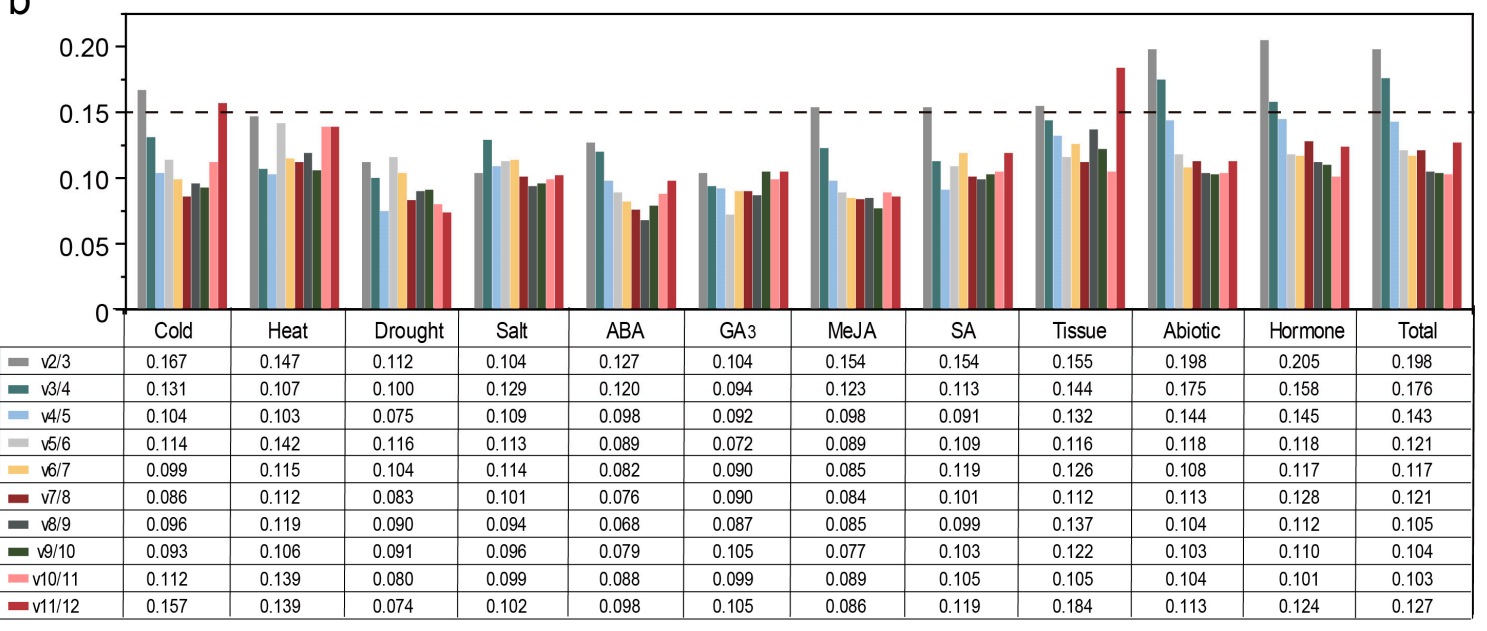

Figure 3. Average expression stability values and pairwise variations indicated by geNorm analysis. (a) The expression stability values (M) and rankings of the 12 candidate reference genes of Cryptomeria fortunei calculated using geNorm. The most and least stable genes are on the right and left, respectively. (b) Optimal number of reference genes determined for C. fortunei.

A single RG usually does not meet the stability requirements for standardization, so two or more RGs are needed to reduce errors and obtain more accurate quantification of target gene expression. GeNorm is based on pairwise changes $\left(V_{n} / V_{n+1}\right)$, using a threshold of 0.15 to determine the optimal number of RGs for each treatment [26]. As shown in Figure 3b, under a single abiotic stress (heat, drought, or salinity) or under ABA or $\mathrm{GA}_{3}$ treatment, the pairwise variation values $\mathrm{V}_{2} / \mathrm{V}_{3}$ were all less than 0.15 , indicating that two suitable RGs were sufficient to standardize these treatment data, whereas under cold, MeJA, and SA treatments and in different tissues, the $\mathrm{V}_{3} / 4$ values were all less than 0.15 , indicating that three RGs were required. Under abiotic stress and various hormone treatments and after merging all samples, the $V_{4} / 5$ values were $0.144,0.145$, and 0.143 , respectively, indicating that four RGs were necessary. 


\subsubsection{NormFinder Analysis}

We also calculated the stability values using NormFinder to evaluate the stability of the expression of these 12 candidate RGs, and low stability values indicated high expression stability [27]. The most stable genes were as follows: CYP and HSP70 under drought stress; actin and $U B C$ under hormone treatments; $C Y P$ and $U B C$ under heat/MeJA/SA/GA $/$ abiotic stress and in the total samples; $r b c l$ and $C Y P, r b c l$ and 18S, and actin and $C Y P$ were the top two most stable genes under cold, salt, and ABA treatment, respectively. Actin, PBL, and HSP70 showed high expression stability in tissues (Table 2). In addition, HIS4, PGK1, and TUA2 were the least stable genes in all samples/treatments (Table 2). Notably, despite the differences in rankings between geNorm and NormFinder, the five most stable genes as well as the three most unstable genes in all samples were basically the same (Figure 3a, Table 2).

Table 2. Expression stability values in C. fortunei under various treatments determined with NormFinder software.

\begin{tabular}{|c|c|c|c|c|c|c|c|c|c|c|c|c|c|}
\hline \multicolumn{2}{|c|}{ Sample } & \multirow{3}{*}{$\begin{array}{c}\mathbf{1} \\
r b c l \\
0.062\end{array}$} & \multirow{2}{*}{$\frac{2}{C Y P}$} & \multirow{2}{*}{$\frac{3}{\text { actin }}$} & \multirow{2}{*}{$\begin{array}{c}4 \\
18 S\end{array}$} & \multirow{2}{*}{$\frac{5}{U B C}$} & \multirow{2}{*}{$\begin{array}{c}\mathbf{6} \\
P B L\end{array}$} & \multirow{2}{*}{$\begin{array}{c}\mathbf{7} \\
P P 2 A\end{array}$} & \multirow{2}{*}{$\begin{array}{c}8 \\
R P L 2\end{array}$} & \multirow{2}{*}{$\begin{array}{c}9 \\
P G K 1\end{array}$} & \multirow{2}{*}{$\frac{10}{H S P 70}$} & \multirow{2}{*}{$\begin{array}{c}\mathbf{1 1} \\
H I S 4\end{array}$} & \multirow{2}{*}{$\frac{12}{T U A 2}$} \\
\hline & gene & & & & & & & & & & & & \\
\hline Cold & stability & & 0.125 & 0.164 & 0.326 & 0.394 & 0.516 & 0.516 & 0.561 & 0.598 & 0.625 & 0.750 & 1.298 \\
\hline \multirow{2}{*}{ Heat } & gene & CYP & $U B C$ & HSP70 & $P B L$ & $P P 2 A$ & actin & RPL2 & $18 S$ & HIS4 & PGK1 & $r b c l$ & TUA2 \\
\hline & stability & 0.104 & 0.316 & 0.340 & 0.441 & 0.444 & 0.534 & 0.608 & 0.609 & 0.637 & 0.721 & 0.951 & 1.142 \\
\hline \multirow{2}{*}{ Drought } & gene & CYP & HSP70 & actin & $U B C$ & $18 S$ & $P B L$ & $r b c l$ & RPL2 & $P P 2 A$ & PGK1 & TUA2 & HIS4 \\
\hline & stability & 0.051 & 0.175 & 0.245 & 0.263 & 0.337 & 0.430 & 0.439 & 0.467 & 0.571 & 0.580 & 0.604 & 0.606 \\
\hline \multirow[b]{2}{*}{ Salt } & gene & $r b c l$ & $18 S$ & actin & HSP70 & $C Y P$ & HIS4 & $U B C$ & $P P 2 A$ & $P B L$ & RPL2 & PGK1 & TUA2 \\
\hline & stability & 0.097 & 0.159 & 0.198 & 0.259 & 0.347 & 0.453 & 0.530 & 0.579 & 0.596 & 0.629 & 0.779 & 0.840 \\
\hline \multirow{2}{*}{ ABA } & gene & actin & $C Y P$ & $18 S$ & $U B C$ & $r b c l$ & $P B L$ & RPL2 & $P P 2 A$ & HSP70 & PGK1 & HIS4 & TUA2 \\
\hline & stability & 0.160 & 0.176 & 0.256 & 0.294 & 0.295 & 0.308 & 0.361 & 0.406 & 0.421 & 0.539 & 0.692 & 0.811 \\
\hline \multirow{2}{*}{$\mathrm{GA}_{3}$} & gene & $U B C$ & $C Y P$ & $P B L$ & $18 S$ & actin & RPL2 & HSP70 & rbcl & $P P 2 A$ & HIS4 & PGK1 & TUA2 \\
\hline & stability & 0.031 & 0.165 & 0.224 & 0.311 & 0.325 & 0.327 & 0.371 & 0.487 & 0.531 & 0.680 & 0.761 & 0.863 \\
\hline \multirow{2}{*}{ MeJA } & gene & CYP & $U B C$ & actin & $P B L$ & $P P 2 A$ & $\mathrm{rbcl}$ & $18 S$ & PGK1 & HSP70 & RPL2 & TUA2 & HIS4 \\
\hline & stability & 0.140 & 0.191 & 0.252 & 0.300 & 0.345 & 0.356 & 0.420 & 0.471 & 0.496 & 0.516 & 0.672 & 0.708 \\
\hline \multirow{2}{*}{ SA } & gene & CYP & $U B C$ & $r b c l$ & actin & RPL2 & HSP70 & HIS4 & $P B L$ & $18 S$ & PGK1 & $P P 2 A$ & TUA2 \\
\hline & stability & 0.214 & 0.233 & 0.241 & 0.255 & 0.367 & 0.408 & 0.539 & 0.585 & 0.616 & 0.716 & 0.740 & 0.982 \\
\hline \multirow{2}{*}{ Tissue } & gene & actin & $P B L$ & HSP70 & $C Y P$ & $P P 2 A$ & $U B C$ & RPL2 & rbcl & $18 S$ & HIS4 & PGK1 & TUA2 \\
\hline & stability & 0.316 & 0.326 & 0.394 & 0.419 & 0.474 & 0.505 & 0.632 & 0.676 & 0.688 & 0.699 & 0.775 & 1.520 \\
\hline \multirow{2}{*}{ Abiotic } & & CYP & $U B C$ & $18 S$ & HSP70 & actin & $P B L$ & RPL2 & $P P 2 A$ & $r b c l$ & HIS4 & PGK1 & TUA2 \\
\hline & stability & 0.203 & 0.395 & 0.395 & 0.448 & 0.486 & 0.517 & 0.558 & 0.598 & 0.700 & 0.718 & 0.722 & 1.016 \\
\hline \multirow{2}{*}{ Hormone } & gene & $U B C$ & actin & $C Y P$ & $r b c l$ & HSP70 & RPL2 & $18 S$ & $P B L$ & $P P 2 A$ & PGK1 & HIS4 & TUA2 \\
\hline & stability & 0.207 & 0.279 & 0.289 & 0.396 & 0.415 & 0.450 & 0.467 & 0.473 & 0.538 & 0.737 & 0.788 & 0.825 \\
\hline \multirow[b]{2}{*}{ Total } & gene & CYP & $U B C$ & actin & HSP70 & $18 S$ & $P B L$ & RPL2 & $P P 2 A$ & $r b c l$ & PGK1 & HIS4 & TUA2 \\
\hline & stability & 0.281 & 0.345 & 0.386 & 0.439 & 0.478 & 0.518 & 0.547 & 0.571 & 0.598 & 0.734 & 0.752 & 1.040 \\
\hline
\end{tabular}

\subsubsection{BestKeeper Analysis}

BestKeeper ranks RGs based on the CV and SD of the average Cq value in the qRTPCR analysis [28]. The most stable genes showed the lowest $\mathrm{SD} \pm \mathrm{CV}$ value, and the SD values were also less than 1 . The stability of $U B C$ ranked first under the MeJA and SA treatments, with $\mathrm{SD} \pm \mathrm{CV}$ values of $0.35 \pm 1.59$ and $0.35 \pm 1.54$, respectively (Table 3$)$. $C Y P$ $(0.35 \pm 1.29)$ was the best RG under cold stress; $P P 2 A(0.42 \pm 1.62)$ ranked first under heat stress; actin ( $0.33 \pm 1.52)$ ranked first under PEG treatment; $r b c l$ ranked first under the ABA and hormone treatments, with $\mathrm{SD} \pm \mathrm{CV}$ values of $0.37 \pm 2.26$ and $0.50 \pm 3.05$, respectively (Table 3). Although $18 \mathrm{~S}$ ranked first under salinity, $\mathrm{GA}_{3}$ treatment, and abiotic stress and in all tissues and samples, with $\mathrm{SD} \pm \mathrm{CV}$ values of $0.38 \pm 6.18,0.46 \pm 7.20,0.47 \pm 7.50$, $0.68 \pm 11.98$, and $0.51 \pm 8.10$, respectively, its $C V$ values were often the highest and were significantly larger than those of the other genes (Table 3). Therefore, $r b c l(0.39 \pm 2.45), C Y P$ $(0.47 \pm 1.76)$, and $U B C$ may be the most stable genes under salt stress, under $\mathrm{GA}_{3}$ treatment, and under abiotic stress/in all tissues/in all samples, respectively (Table 3). BestKeeper suggested that $18 S, U B C$, actin, and CYP were the most stable RGs for merging the data 
of all samples (Table 3). At the same time, we analyzed the genes with SD values $\geq 1$ and found that TUA2, HIS4, and PGK1 were the least stable RGs (Supplementary Table S1).

Table 3. Expression stability values of candidate reference genes calculated by BestKeeper.

\begin{tabular}{|c|c|c|c|c|c|c|c|c|c|c|c|c|c|}
\hline \multicolumn{2}{|c|}{ Sample } & 1 & 2 & 3 & 4 & 5 & 6 & 7 & 8 & 9 & 10 & 11 & 12 \\
\hline \multirow{3}{*}{ Cold } & gene & $C Y P$ & $U B C$ & actin & $\mathrm{rbcl}$ & $18 S$ & $P B L$ & $P P 2 A$ & $R P L 2$ & PGK1 & HSP70 & HIS4 & TUA2 \\
\hline & SD & 0.35 & 0.38 & 0.44 & 0.46 & 0.47 & 0.70 & 0.71 & 0.74 & 0.76 & 0.79 & 1.00 & 1.31 \\
\hline & $\mathrm{CV}$ & 1.29 & 1.69 & 1.97 & 2.94 & 7.37 & 2.73 & 2.79 & 3.87 & 3.47 & 3.46 & 3.76 & 5.75 \\
\hline \multirow{3}{*}{ Heat } & gene & $P P 2 A$ & CYP & $18 S$ & HSP70 & $P B L$ & $U B C$ & HIS4 & actin & $r b c l$ & RPL2 & PGK1 & TUA2 \\
\hline & SD & 0.42 & 0.66 & 0.67 & 0.68 & 0.78 & 0.78 & 0.80 & 0.92 & 1.04 & 1.04 & 1.12 & 1.19 \\
\hline & $\mathrm{CV}$ & 1.62 & 2.36 & 10.67 & 2.91 & 2.98 & 3.49 & 2.97 & 4.08 & 5.52 & 4.68 & 4.78 & 4.99 \\
\hline \multirow{3}{*}{ Drought } & gene & actin & $18 S$ & $U B C$ & CYP & HSP70 & TUA2 & RPL2 & $P P 2 A$ & rbcl & PGK1 & $P B L$ & HIS4 \\
\hline & SD & 0.33 & 0.35 & 0.35 & 0.42 & 0.53 & 0.58 & 0.66 & 0.69 & 0.74 & 0.82 & 0.88 & 1.05 \\
\hline & $\mathrm{CV}$ & 1.52 & 5.60 & 1.61 & 1.57 & 2.33 & 2.60 & 3.31 & 2.75 & 4.79 & 3.81 & 3.46 & 4.22 \\
\hline \multirow{3}{*}{ Salt } & gene & $18 S$ & $r b c l$ & actin & $U B C$ & CYP & HSP70 & TUA2 & $P B L$ & $P P 2 A$ & HIS4 & RPL2 & PGK1 \\
\hline & SD & 0.38 & 0.39 & 0.40 & 0.45 & 0.57 & 0.60 & 0.68 & 0.72 & 0.78 & 0.84 & 0.96 & 1.12 \\
\hline & $\mathrm{CV}$ & 6.18 & 2.45 & 1.78 & 2.03 & 2.11 & 2.65 & 3.08 & 2.85 & 3.06 & 3.28 & 4.88 & 5.15 \\
\hline \multirow{3}{*}{$\mathrm{ABA}$} & gene & $r b c l$ & $P P 2 A$ & $U B C$ & $18 S$ & CYP & actin & $P B L$ & RPL2 & PGK1 & HSP70 & TUA2 & HIS4 \\
\hline & SD & 0.37 & 0.47 & 0.56 & 0.66 & 0.72 & 0.74 & 0.87 & 0.87 & 0.92 & 0.96 & 1.05 & 1.15 \\
\hline & $\mathrm{CV}$ & 2.26 & 1.81 & 2.51 & 9.82 & 2.64 & 3.27 & 3.32 & 4.28 & 4.11 & 4.12 & 4.50 & 4.43 \\
\hline \multirow{3}{*}{$\mathrm{GA}_{3}$} & gene & $18 S$ & $C Y P$ & $r b c l$ & RPL2 & $U B C$ & actin & $P B L$ & $P P 2 A$ & HIS4 & HSP70 & TUA2 & PGK1 \\
\hline & SD & 0.46 & 0.47 & 0.47 & 0.53 & 0.59 & 0.65 & 0.66 & 0.69 & 0.78 & 0.78 & 0.79 & 0.96 \\
\hline & $\mathrm{CV}$ & 7.20 & 1.76 & 2.88 & 2.67 & 2.71 & 2.95 & 2.56 & 2.74 & 3.00 & 3.47 & 3.51 & 4.41 \\
\hline \multirow{3}{*}{ MeJA } & gene & $U B C$ & $18 S$ & $\mathrm{rbcl}$ & $P P 2 A$ & $C Y P$ & PGK1 & actin & $P B L$ & TUA2 & RPL2 & HIS4 & HSP70 \\
\hline & SD & 0.35 & 0.36 & 0.45 & 0.61 & 0.63 & 0.65 & 0.69 & 0.70 & 0.92 & 0.95 & 0.95 & 1.09 \\
\hline & $\mathrm{CV}$ & 1.59 & 5.73 & 2.72 & 2.41 & 2.33 & 2.88 & 3.12 & 2.75 & 4.11 & 4.69 & 3.80 & 4.90 \\
\hline \multirow{3}{*}{ SA } & gene & $U B C$ & $r b c l$ & CYP & actin & RPL2 & HSP70 & $P B L$ & $18 S$ & HIS4 & PGK1 & TUA2 & $P P 2 A$ \\
\hline & SD & 0.35 & 0.35 & 0.41 & 0.44 & 0.54 & 0.64 & 0.82 & 0.85 & 0.87 & 0.91 & 0.98 & 1.05 \\
\hline & $\mathrm{CV}$ & 1.54 & 2.19 & 1.52 & 1.96 & 2.74 & 2.82 & 3.24 & 14.33 & 3.43 & 4.09 & 4.33 & 4.20 \\
\hline \multirow{3}{*}{ Tissue } & gene & $18 S$ & $U B C$ & actin & CYP & $P B L$ & PGK1 & HIS4 & HSP70 & RPL2 & $P P 2 A$ & $\mathrm{rbcl}$ & TUA2 \\
\hline & SD & 0.68 & 0.70 & 0.92 & 0.95 & 0.97 & 1.10 & 1.11 & 1.22 & 1.22 & 1.25 & 1.50 & 2.39 \\
\hline & $\mathrm{CV}$ & 11.98 & 3.34 & 4.39 & 3.69 & 3.94 & 5.15 & 4.58 & 5.75 & 5.92 & 5.06 & 8.84 & 10.33 \\
\hline \multirow{3}{*}{ Abiotic } & gene & $18 S$ & $U B C$ & actin & CYP & $P P 2 A$ & HSP70 & $P B L$ & PGK1 & TUA2 & HIS4 & $r b c l$ & RPL2 \\
\hline & SD & 0.47 & 0.54 & 0.61 & 0.66 & 0.70 & 0.75 & 0.83 & 1.02 & 1.12 & 1.23 & 1.24 & 1.26 \\
\hline & $\mathrm{CV}$ & 7.50 & 2.45 & 2.73 & 2.42 & 2.74 & 3.29 & 3.22 & 4.60 & 4.92 & 4.73 & 7.56 & 6.24 \\
\hline \multirow{3}{*}{ Hormone } & gene & $r b c l$ & $U B C$ & $18 S$ & CYP & actin & $R P L 2$ & $P B L$ & $P P 2 A$ & PGK1 & HSP70 & HIS4 & TUA2 \\
\hline & SD & 0.50 & 0.56 & 0.60 & 0.62 & 0.67 & 0.75 & 0.78 & 0.82 & 0.88 & 0.91 & 0.96 & 1.03 \\
\hline & $\mathrm{CV}$ & 3.05 & 2.51 & 9.51 & 2.29 & 3.03 & 3.73 & 3.03 & 3.21 & 3.98 & 4.01 & 3.74 & 4.52 \\
\hline \multirow{3}{*}{ Total } & gene & $18 S$ & $U B C$ & actin & CYP & $P P 2 A$ & $P B L$ & HSP70 & $P G K 1$ & $r b c l$ & RPL2 & HIS4 & TUA2 \\
\hline & SD & 0.51 & 0.61 & 0.67 & 0.71 & 0.74 & 0.80 & 0.86 & 0.87 & 0.92 & 0.97 & 1.08 & 1.13 \\
\hline & $\mathrm{CV}$ & 8.10 & 2.77 & 3.03 & 2.64 & 2.92 & 3.15 & 3.81 & 3.94 & 5.60 & 4.78 & 4.20 & 4.95 \\
\hline
\end{tabular}

\subsection{Comprehensive Stability Analysis of the RGs}

To reduce the influence of the limitations and deviations of a single algorithm, the stability of the RGs was analyzed by using the geometric mean of four algorithms (delta $\mathrm{Ct}$, geNorm, NormFinder, and BestKeeper) to determine the best RGs. The comprehensive RG ranking results are shown in Figure 4. Under cold stress, $r b c l, C Y P$, and actin was the best combination; under drought stress, HSP70 and CYP were the most stable RGs; under high-salinity stress, $r b c l$ and $18 \mathrm{~S}$ rRNA exhibited the highest stability; under ABA treatment, $C Y P$ and actin showed the highest stability; and PBL, actin, and CYP were the most stable RGs in different tissues. $C Y P$ and $U B C$ showed the highest stability under heat stress, under $\mathrm{GA}_{3}$ treatment, under MeJA/SA treatment (also including actin), under hormone treatments (also including actin and $r b c l$ ), and under abiotic stress/in all samples (also including actin and 18S). 

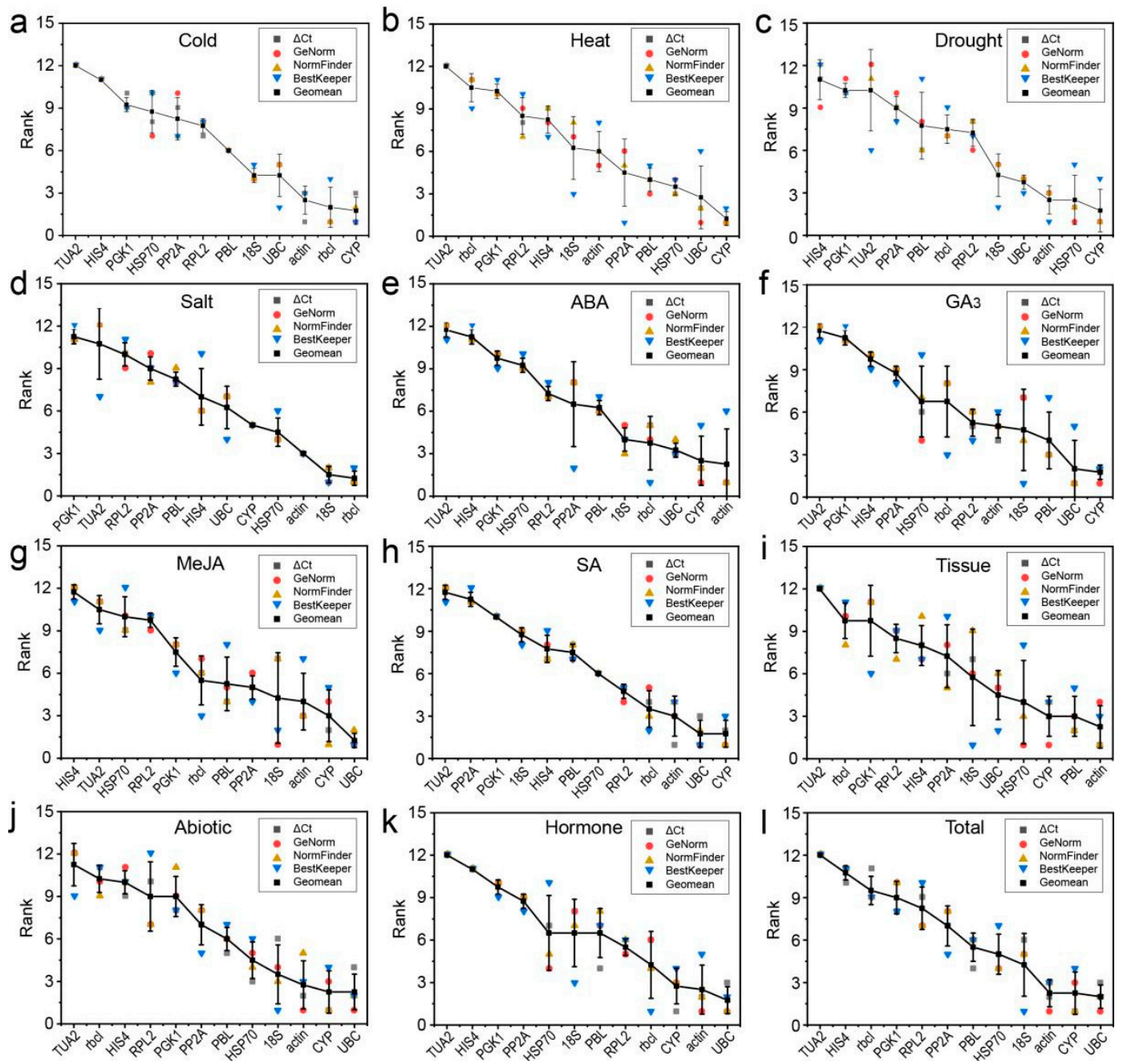

Figure 4. Comprehensive rankings of the $12 \mathrm{RGs}$ in $\mathrm{C}$. fortunei calculated as the geometric mean of the four types of rankings for each group of samples. (a) $4{ }^{\circ} \mathrm{C}$ cold stress; (b) $42{ }^{\circ} \mathrm{C}$ heat stress; (c) drought stress simulated by $15 \%$ PEG-6000 treatment; (d) salt stress simulated by $200 \mathrm{mM} \mathrm{NaCl}$ treatment; (e) $200 \mu \mathrm{M} \mathrm{ABA}$ treatment; (f) $200 \mu \mathrm{M} \mathrm{GA} 3$ treatment; (g) $200 \mu \mathrm{M} \mathrm{MeJA}$ treatment; (h) $200 \mu \mathrm{M}$ SA treatment; (i) in different tissues (stems, tender needles, needles, cones, and seeds); (j) under abiotic stress; (k) under hormone treatments; in (1) in total samples.

We further used the RefFinder program to comprehensively verify the rankings of candidate RGs, and the results were basically the same as those for the geometric mean, with only slight differences under MeJA-treated samples. For example, UBC, CYP, and $18 S$ were the best RGs under MeJA stress, followed by actin. In addition, these stable RGs selected under various experimental conditions were basically the five most stable genes selected by the four algorithms (or at least two, for example, geNorm and BestKeeper) (Figure 5). By contrast, we conducted statistical analysis of the three most unstable RGs determined by the two comprehensive evaluation methods, and the results showed that TUA2, PGK1, and HIS4 were the least stable RGs (Supplementary Table S2). 

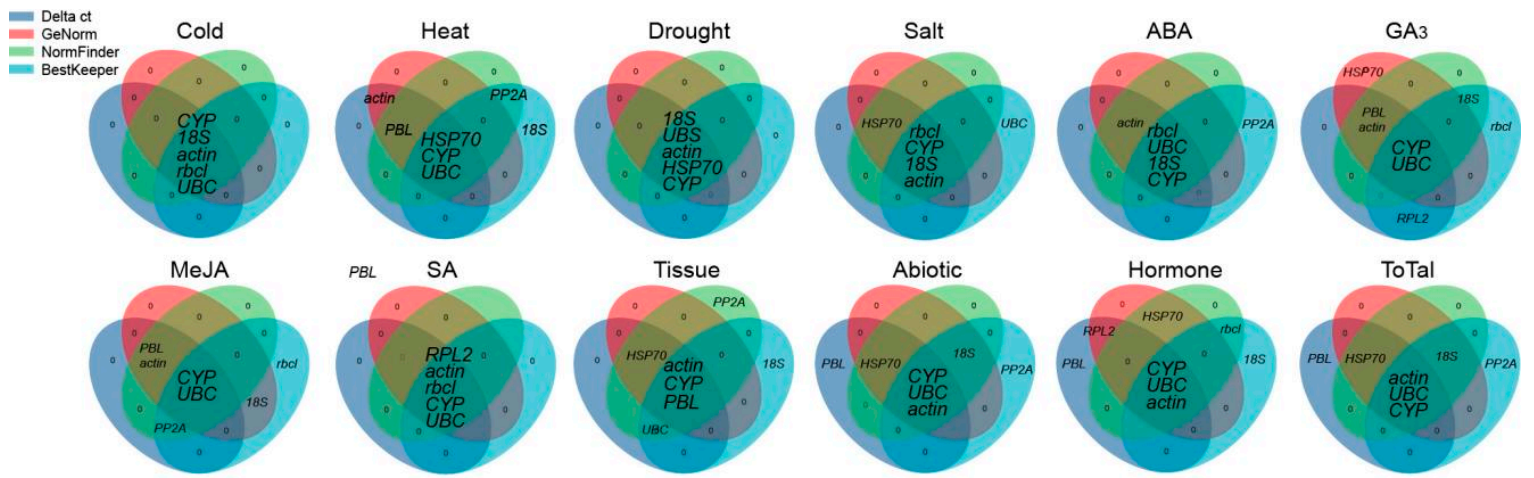

Tissue
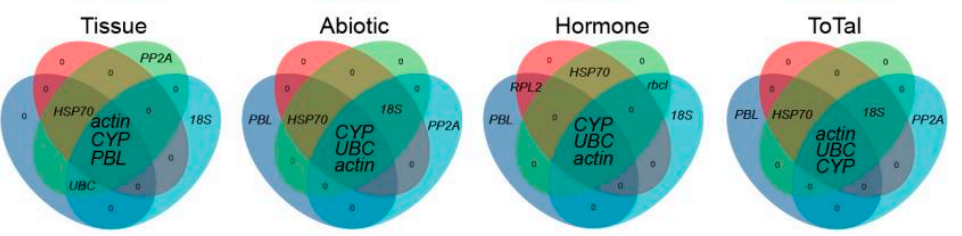

Figure 5. The 5 most stable reference genes (RGs) indicated by delta Ct analysis, geNorm, NormFinder, and BestKeeper. The blue, pink, green, and sky-blue circles each contain the 5 most stable RGs determined by delta Ct analysis, geNorm, NormFinder, and BestKeeper, respectively. The genes in the overlapping area are those confirmed as the 5 most stable RGs by more than one algorithm.

\subsection{Validation of the Stability of RGs}

To verify the accuracy of the stable expression of RGs, three genes (CAT, MAPK1, and MAPK6) were selected as target genes. The expression of the antioxidant $C A T$ gene is induced by many abiotic stress factors, including cold, heat, drought, and salinity [30]; mitogen-activated protein kinases (MAPK1 and MAPK6) are important transmitters of signals from the cell surface to the inside of the nucleus and play an important role in the regulation of plant growth and development and abiotic stress resistance and tolerance [31-33]. We combined the geNorm pairwise change $\left(V_{n} / V_{n+1}\right)$ results, selected multiple best and the worst RGs according to the comprehensive ranking results for each treatment/tissue, and used these RGs to standardize gene expression data.

In different tissues, the expression patterns obtained when using the most and the least stable RGs under specific experimental conditions were different. More specifically, using stable RGs, CAT and MAPK6 showed the highest expression ( $<3$ times, compared to needles) in stems, whereas using an unstable internal control, the expression of $C A T$ and MAPK6 was highest in seeds (15-42 times higher than that in needles), and the expression increased significantly (Figure 6i and Figure 8i). In addition, when using stable and unstable RGs, although MAPK1 was the most highly expressed in seeds, the difference was more than 20-fold (Figure 7i).

Under different treatments, when using different stable RGs, CAT, MAPK1, and MAPK6 showed similar expression patterns, but their expression levels differed between treatments (Figures 6-8). More specifically, under abiotic stress, such as cold and heat, $C A T, M A P K 1$, and MAPK6 were upregulated or downregulated when using stable RGs, but the magnitude was low; when the most unstable RGs were used for normalization, the expression of CAT, MAPK1, and MAPK6 fluctuated significantly. Overall, the results show that if different RGs are used to correct the expression of target genes in qRT-PCR analysis, different results will be obtained. If the RGs are incorrectly selected, the relative expression levels of the target genes may be incorrectly estimated. 

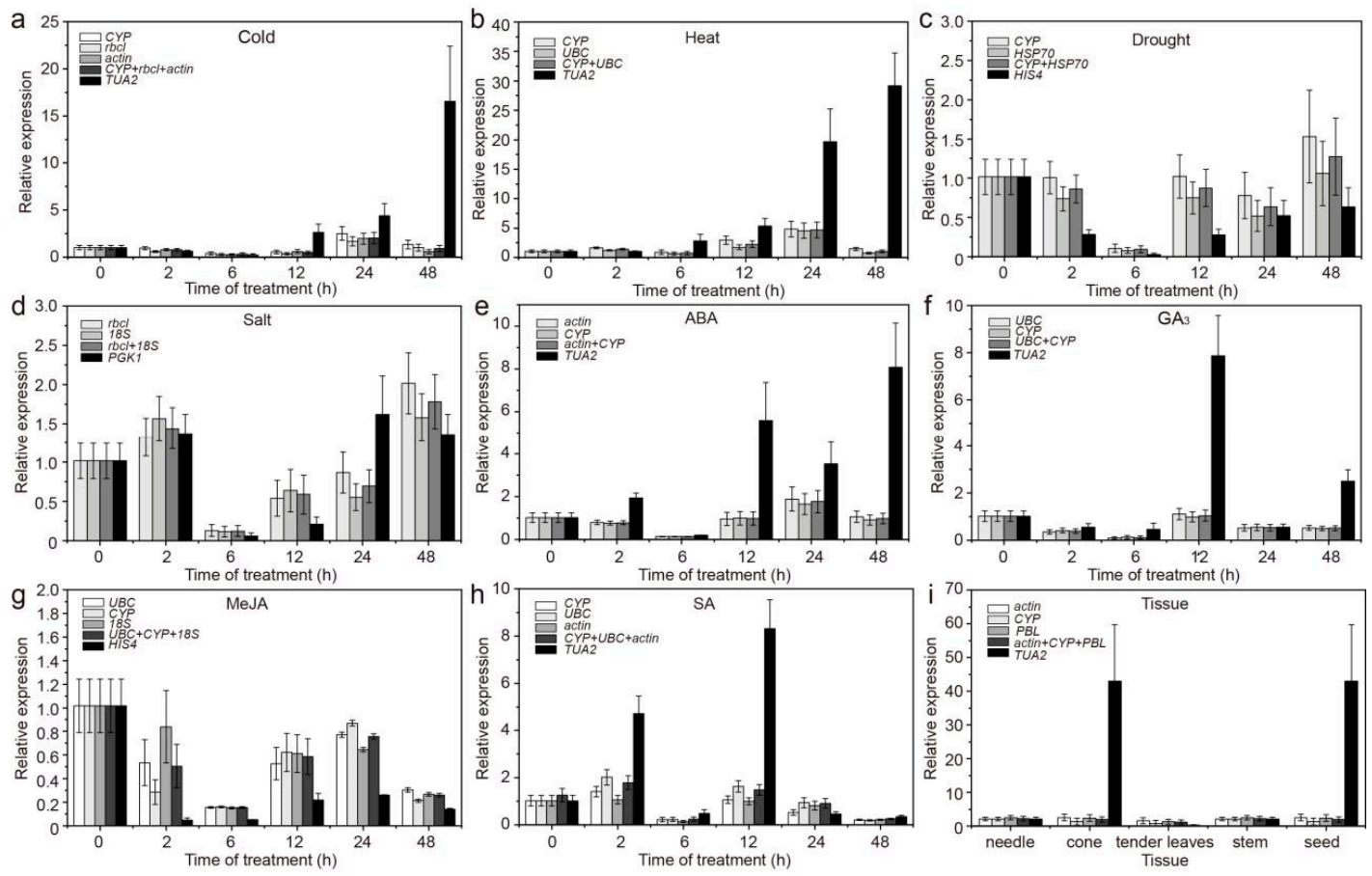

Figure 6. Relative expression levels of $C A T$ under different experimental conditions normalized to the top two/three stable genes and the least stable genes. (a) $4{ }^{\circ} \mathrm{C}$ cold stress; (b) $42{ }^{\circ} \mathrm{C}$ heat stress; (c) drought stress simulated by $15 \%$ PEG-6000 treatment; (d) salt stress simulated by $200 \mathrm{mM} \mathrm{NaCl}$ treatment; (e) $200 \mu \mathrm{M}$ ABA treatment; (f) $200 \mu \mathrm{M}$ GA 3 treatment; (g) $200 \mu \mathrm{M}$ MeJA treatment; (h) $200 \mu \mathrm{M}$ SA treatment; and (i) in different tissues (stems, tender needles, needles, cones, and seeds). The error bars represent standard deviations (SDs) $(n=3)$.
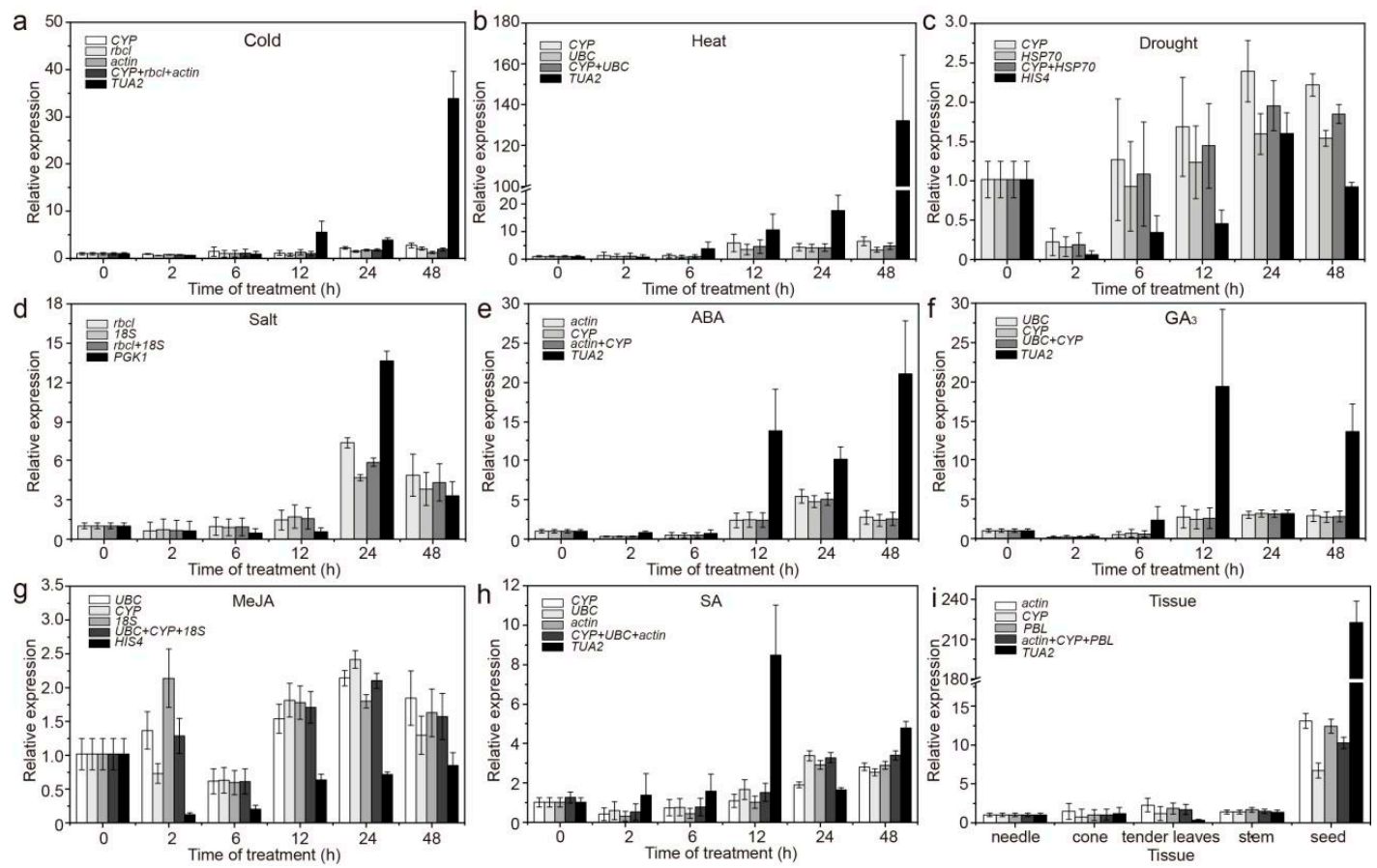

Figure 7. Relative expression levels of $M A P K 1$ under different experimental conditions normalized to the top two/three most stable genes and the least stable genes. (a) $4{ }^{\circ} \mathrm{C}$ cold stress; (b) $42{ }^{\circ} \mathrm{C}$ heat stress; (c) drought stress simulated by 15\% PEG-6000 treatment; (d) salt stress simulated by $200 \mathrm{mM} \mathrm{NaCl}$ treatment; (e) $200 \mu \mathrm{M}$ ABA treatment; (f) $200 \mu \mathrm{M} \mathrm{GA}$ treatment; (g) $200 \mu \mathrm{M}$ MeJA treatment; (h) $200 \mu \mathrm{M}$ SA treatment; and (i) in different tissues (stems, tender needles, needles, cones, and seeds). The error bars represent standard deviations (SD) $(n=3)$. 

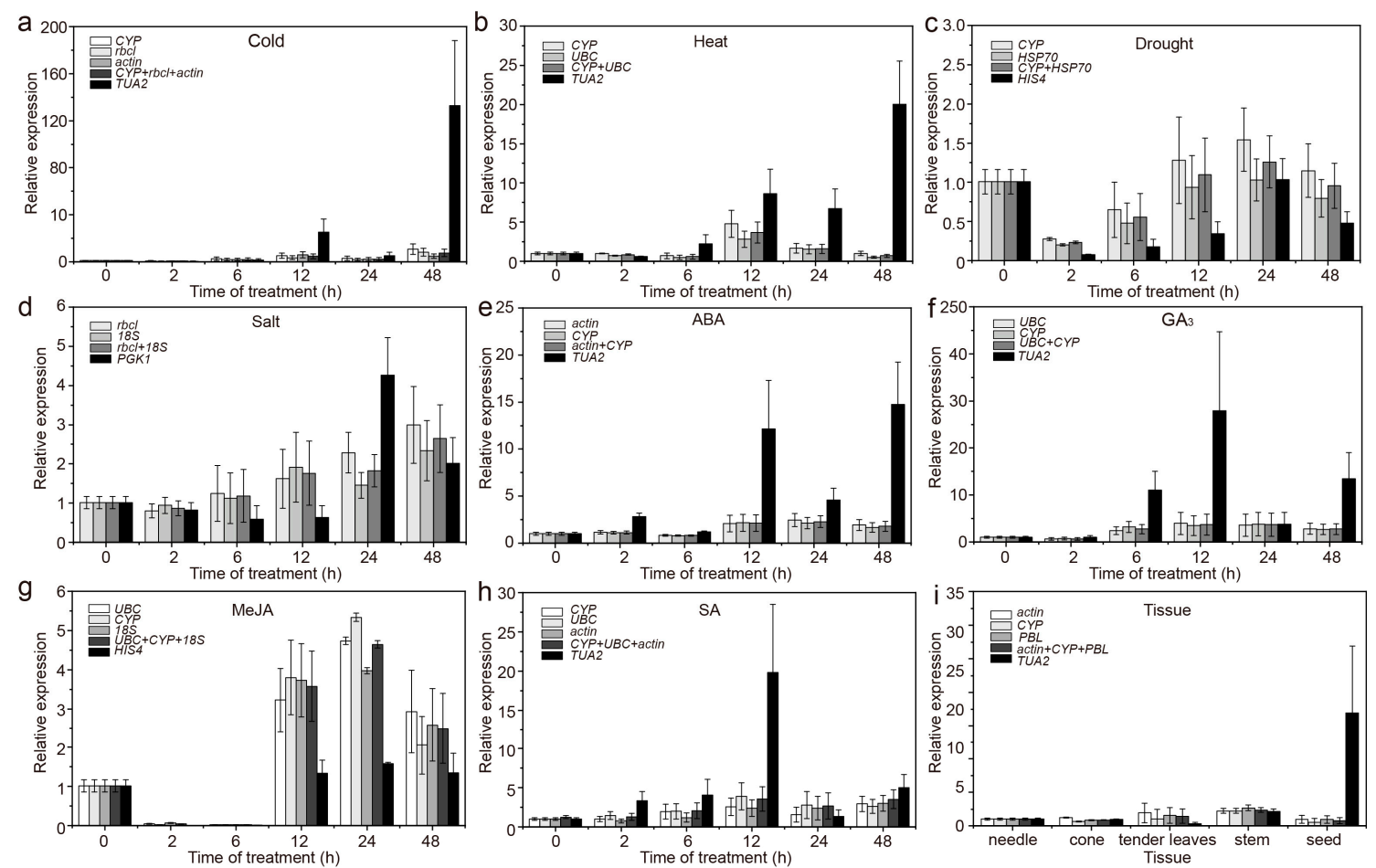

Figure 8. Relative expression levels of MAPK6 under different experimental conditions normalized to the top two/three most stable genes and the least stable genes. (a) $4{ }^{\circ} \mathrm{C}$ cold stress; (b) $42{ }^{\circ} \mathrm{C}$ heat stress; (c) drought stress simulated by 15\% PEG-6000 treatment; (d) salt stress simulated by $200 \mathrm{mM} \mathrm{NaCl}$ treatment; (e) $200 \mu \mathrm{M}$ ABA treatment; (f) $200 \mu \mathrm{M} \mathrm{GA} 3$ treatment; (g) $200 \mu \mathrm{M}$ MeJA treatment; (h) $200 \mu \mathrm{M}$ SA treatment; and (i) in different tissues (stems, tender needles, needles, cones, and seeds). The error bars represent standard deviations (SD) $(n=3)$.

\section{Discussion}

qRT-PCR has been widely used in the study of gene expression in recent years because of its rapidness and high sensitivity, accuracy, and reproducibility [1-4]. The key to obtaining correct gene expression results is to select the appropriate RGs to standardize the data. Improper selection of RGs may lead to incorrect experimental conclusions. However, there is no report of systematic selection of suitable RGs of $C$. fortunei for qRT-PCR analysis.

In this study, we selected 12 candidate RGs, most of which have been studied in different plants, such as Masson pine (Pinus massoniana) [15], cortex eucommiae (Eucommia ulmoides) [34], and soybean (Glycine max) [2]. In terms of standardization and quality, the PCR efficiency of candidate RG primer pairs ranged from $95.14 \%$ to $109.94 \%$, and the $R^{2}$ of linear amplification ranged from 0.980 to 0.997 (Table 1). These results indicate that the primer pairs used for these RGs have high accuracy, efficiency, and sensitivity. The average $\mathrm{Ct}$ values of candidate RGs varied from 6.241 (18S) to 26.958 (for CYP) (Figure 1). Regarding Chinese tulip trees (Liriodendron chinense) [14] and E. ulmoides [34], the candidate RGs also exhibited different expression levels in the test materials, and the average $\mathrm{Ct}$ values of candidate RGs ranged between 17 and 29. These results indicate that in a given whole sample, the expression levels of 12 RGs were in a wide range, and none of the RGs had constant expression levels in different samples. Therefore, it is necessary to select suitable RGs for gene standardization under specific experimental conditions before selecting RGs as an internal control for qRT-PCR analysis.

To date, many algorithms have been widely used for screening and evaluating RG stability. In this study, four algorithms (delta Ct, NormFinder, geNorm, and Bestkeeper) were used to analyze the expression of 12 RGs in different tissue samples or under different abiotic stress/hormone treatments in C. fortunei. We found that the top five genes selected by various algorithms were generally similar (Figure 5). For example, in all samples, the top five genes of the four algorithms all included UBC, actin, and CYP; in addition, 
the genes selected by GeNorm (NormFinder), delta $\mathrm{Ct}$, and BestKeeper also included $18 S$ and HSP70, PBL and HSP70, and $18 S$ and PP2A, respectively. However, there were indeed some differences between the stability analysis results obtained using different algorithms (Figures 2 and 3 and Tables 2 and 3). For example, in all samples, GeNorm and NormFinder analyses indicated that UBC, actin, CYP, and HSP70 were the most stable genes; delta $C t$ thought that $C Y P$, actin, $U B C$, and $P B L$ showed the highest stability; while BestKeeper showed that 18S, UBC, actin, and CYP performed better than the other genes. This phenomenon has also been observed in studies on RGs in plants, such as citrus (Citrus reticulata) [35], L. chinense [14], and wild barley (Hordeum brevisubulatum) [4]. It is speculated that each algorithm has different principles and methods for evaluating stability, so the final conclusions are also different.

In the actual application process, it is necessary to comprehensively consider the analysis results provided by delta Ct, NormFinder, GeNorm, and BestKeeper [4,36,37]. To avoid differences caused by the software, the geometric mean method or RefFinder can be used to comprehensively analyze the results obtained with different software when selecting RGs, and finally, the optimal RGs can be obtained. Fortunately, we found that the results of the geometric mean method for each treatment/tissue were similar to the RefFinder results (Figure 4 and Supplementary Table S3), indicating that under cold stress, rbcl, CYP, and actin was the best combination; under drought, high-salinity stress, or under ABA treatment, HSP70 and CYP, rbcl and 18S, or CYP and actin were the most stable RGs; and PBL, actin, and CYP were the most stable RGs in different tissues. CYP and $U B C$ showed the highest stability under heat stress, under $G_{3}$ treatment, under SA treatment (also including actin), under MeJA treatment (also including 18S), under hormone treatments (also including actin and $r b c l$ ), and under abiotic stress/in all samples (also including actin and 18S). There were also certain differences in the optimal combination of RGs under different treatments/in different tissues of the same species. Similar results were also obtained via research on differences in RGs in H. hamabo [1], E. ulmoides [34], $P$. massoniana [15], and other plants.

Although no RG was consistently the best under the various experimental conditions, CYP , UBC, actin, and $18 S$ were proposed as good choices for studying gene expression in C. fortunei, whereas TUA2, PGK1, and HIS4 were the least stable RGs. This is similar to the results for RGs in other plants. For example, in the evaluation of the stability of RGs in different tissues of P. miliaceum and under stress treatments, it was found that $18 S$ was suitable as an RG [12]; actin was determined to be the most suitable internal control gene in P. massoniana by qRT-PCR analysis under stress (salinity, drought, cold, and heat) [15] and was the most stably expressed RG in H. hamabo in all samples (in different tissues and under abiotic stress) [1]; CYP was a stable RG under abiotic stress in pineapple (Ananas comosus) [38]; and UBC was the stable RG for the groups "natural growth", "abiotic stress", and "total" in E. ulmoides [34]. However, there were some differences in RGs among species; for example, TUA was the most stable RG in all processed samples of P. massoniana [15]. In a study of Nitraria tangutorum, HIS was suitable for normalization in different organs, under abiotic stress and hormone stimuli [39]. These results are verified by the fact that RGs exhibit species-specific expression.

To compare normalization results, the best and the worst ranked genes were used for normalization of $C A T, M A P K 1$, and $M A P K 6$ expression. Under various stresses or in different tissues, inappropriate candidate RGs were used, resulting in incorrect estimation of the expression (underestimation/overestimation) or expression trends (Figures 6-8), emphasizing that the use of unsuitable RGs could lead to unexpected and uncertain results. This study screened only 12 commonly used RGs and selected samples of $C$. fortunei, that is, a sample of different tissues and samples under eight treatments (hormone treatments and abiotic stress). Follow-up research should expand the screening range of RGs and develop new RGs that are suitable for the experimental system to provide a theoretical basis for the development and application of RGs of $C$. fortunei and aid molecular biological research on C. fortunei. 


\section{Conclusions}

Taken together, for the first time, this study systematically and comprehensively screened the best RGs for $C$. fortunei under different abiotic stress factors, under hormone treatments, and in different tissues. The results indicate that the following genes could be used as RGs under various experimental conditions: $C Y P$ and $H S P 70$ under drought; $C Y P$ and actin under ABA treatment; $r b c l, C Y P$, and actin under cold stress; $r b c l$ and $18 S$ under high-salinity stress; $P B L$, actin, and $C Y P$ in different tissues; and $C Y P$ and $U B C$ showed the highest stability under heat stress, under $\mathrm{GA}_{3}$ treatment, under SA treatment (also including actin), under MeJA treatment (also including 18S), under hormone treatments (also including actin and $r b c l$ ), and under abiotic stress/in all samples (also including actin and 18S). Although no RG was consistently the best under various experimental conditions, CYP , UBC, actin, and $18 S$ were proposed as good choices for studying gene expression in C. fortunei. These suitable RGs will help to improve the accuracy of gene expression analysis of $C$. fortunei and aid further research on stress ecology and gene functions of C. fortunei.

Supplementary Materials: The following are available online at https://www.mdpi.com/article/ 10.3390/genes12060791/s1, Figure S1: specificity of each candidate reference gene primer pair, Table S1: statistics for genes with SD values $\geq 1$ under different treatments/in different tissues, Table S2: statistics for the last three RGs in the stability rankings obtained via the two comprehensive evaluation methods, Table S3: top five genes ranked by the five tools.

Author Contributions: Conceptualization, J.X. (Jin Xu); data curation, J.X. (Jin Xu); formal analysis, Y.Z., L.Z., J.X. (Jinyu Xue), H.H., J.Y. and J.C.; investigation, H.H. and J.Y.; writing —original draft, Y.Z.; writing - review and editing, J.X. (Jin $\mathrm{Xu}$ ) and Y.Z.; project administration, J.X. (Jin $\mathrm{Xu}$ ); supervision, J.X. (Jin $\mathrm{Xu}$ ); funding acquisition, J.X. (Jin $\mathrm{Xu}$ ) and Y.Z. All authors have read and agreed to the published version of the manuscript.

Funding: This research was funded by China's State Forestry Administration, Forestry Public Welfare Industry Research (201304104) and Priority Academic Program Development of Jiangsu Higher Education Institutions (PAPD).

Conflicts of Interest: The authors declare no conflict of interest.

\section{References}

1. Ni, L.; Wang, Z.; Liu, L.; Guo, J.; Li, H.; Gu, C. Selection and verification of candidate reference genes for gene expression by quantitative RT-PCR in Hibiscus hamabo Sieb. et Zucc. Trees 2019, 33, 1591-1601. [CrossRef]

2. Hu, R.; Fan, C.; Li, H.; Zhang, Q.; Fu, Y.F. Evaluation of putative reference genes for gene expression normalization in soybean by quantitative real-time RT-PCR. BMC Mol. Biol. 2009, 10, 93. [CrossRef]

3. Nolan, T.; Hands, R.E.; Bustin, S.A. Quantification of mRNA using real-time RT-PCR. Nat. Protoc. 2006, 1, 1559-1582. [CrossRef] [PubMed]

4. Zhang, L.; Zhang, Q.; Jiang, Y.; Li, Y.; Zhang, H.; Li, R. Reference genes identification for normalization of qPCR under multiple stresses in Hordeum brevisubulatum. Plant Methods 2018, 14, 110. [CrossRef] [PubMed]

5. Saddhe, A.A.; Malvankar, M.R.; Kumar, K. Selection of reference genes for quantitative real-time PCR analysis in halophytic plant Rhizophora apiculata. Peer] 2018, 6, e5226. [CrossRef] [PubMed]

6. Menon, T.G.; Soniya, E.V. Isolation and characterization of salt-induced genes from Rhizophora apiculata Blume, a true mangrove by suppression subtractive hybridization. Curr. Sci. India 2014, 107, 650-655.

7. Xu, X.; Yang, Z.; Sun, X.; Zhang, L.; Fang, Z. Selection of reference genes for quantitative real-time PCR during flower bud development in CMS7311 of heading Chinese cabbage (Brassica rapa L. ssp. pekinensis). Acta Physiol. Plant 2014, 36, 809-814. [CrossRef]

8. Mou, S.; Zhang, X.; Miao, J.; Zheng, Z.; Xu, D.; Ye, N. Reference genes for gene expression normalization in Chlamydomonas sp. ICE-L by quantitative real-time RT-PCR. J. Plant Biochem. Biot. 2014, 24, 276-282. [CrossRef]

9. Tong, Z.; Gao, Z.; Wang, F.; Zhou, J.; Zhang, Z. Selection of reliable reference genes for gene expression studies in peach using real-time PCR. BMC Mol. Biol. 2009, 10, 71. [CrossRef]

10. Remans, T.; Smeets, K.; Opdenakker, K.; Mathijsen, D.; Vangronsveld, J.; Cuypers, A. Normalisation of real-time RT-PCR gene expression measurements in Arabidopsis thaliana exposed to increased metal concentrations. Planta 2008, 227, 1343-1349. [CrossRef]

11. Li, X.; Zhang, D.; Li, H.; Gao, B.; Yang, H.; Zhang, Y.; Wood, A.J. Characterization of reference genes for RT-qPCR in the desert moss Syntrichia caninervis in response to abiotic stress and desiccation/rehydration. Front. Plant Sci. 2015, 6, 38. [CrossRef] 
12. Yue, H.; Deng, P.; Liu, S.; Wang, M.; Song, W.; Nie, X. Selection and evaluation of reference genes for quantitative gene expression analysis in broomcorn millet (Panicum miliaceum L.). J. Plant Biol. 2016, 59, 435-443. [CrossRef]

13. Borowski, J.M.; Galli, V.; Messias, R.D.S.; Perin, E.C.; Rombaldi, C.V. Selection of candidate reference genes for real-time PCR studies in lettuce under abiotic stresses. Planta 2014, 239, 1187. [CrossRef]

14. Tu, Z.; Hao, Z.; Zhong, W.; Li, H. Identification of suitable reference genes for RT-qPCR assays in Liriodendron chinense (Hemsl.) Sarg. Forests 2019, 10, 441. [CrossRef]

15. Zhu, P.; Ma, Y.; Zhu, L.; Chen, Y.; Ji, K. Selection of suitable reference genes in Pinus massoniana Lamb. under different abiotic stresses for qPCR normalization. Forests 2019, 10, 632. [CrossRef]

16. Takenaka, C.; Yamada, T.; Iwata, S. Ethylene emission from seedlings of hinoki (Chamaecyparis obtusa) and sugi (Cryptomeria japonica) under acidic stress. J. Forest Res. 1996, 1, 183-185. [CrossRef]

17. Zhang, Y.; Zhu, Q.; Guo, Z.; Yang, J.; Mo, J.; Cui, J.; Hu, H.; Xu, J. Individual Cryptomeria fortunei Hooibrenk clones show varying degrees of chilling stress resistance. Forests 2020, 11, 189. [CrossRef]

18. Konpka, B.; Noguchi, K.; Sakata, T.; Takahashi, M.; Konôpková, Z. Effects of simulated drought stress on the fine roots of Japanese cedar (Cryptomeria japonica) in a plantation forest on the Kanto Plain, eastern Japan. J. Forest Res. 2007, 12, 143-151. [CrossRef]

19. Li, Q.; Wang, Y.; Yan, L.; Liu, C.; Wu, D.; Han, B.; Li, L. Evaluation of cold resistance of different genotypes of Cryptomeria japonica under low temperature stress. Shandong Agr. Sci. 2020, 52, 50-53. (In Chinese) [CrossRef]

20. Futamura, N.; Tani, N.; Tsumura, Y.; Nakajima, N.; Sakaguchi, M.; Shinohara, K. Characterization of genes for novel thaumatinlike proteins in Cryptomeria japonica. Tree Physiol. 2006, 26, 51-62. [CrossRef] [PubMed]

21. Guo, Z.; Hua, H.; Xu, J.; Mo, J.; Zhao, H.; Yang, J. Cloning and functional analysis of lignin biosynthesis genes $C f 4 C L$ and CfCCoAOMT in Cryptomeria fortunei. Genes 2019, 10, 619. [CrossRef] [PubMed]

22. Mishima, K.; Fujiwara, T.; Iki, T.; Kuroda, K.; Yamashita, K.; Tamura, M.; Fujisawa, Y.; Watanabe, A. Transcriptome sequencing and profiling of expressed genes in cambial zone and differentiating xylem of Japanese cedar (Cryptomeria japonica). BMC Genom. 2014, 15, 219. [CrossRef]

23. Alzohairy, A.M. BioEdit: An important software for molecular biology. GERF Bull. Biosci. 2011, 2, 60-61.

24. Whistler, T.; Chiang, C.; Lonergan, W.; Hollier, M.; Unger, E.R. Implementation of exon arrays: Alternative splicing during T-cell proliferation as determined by whole genome analysis. BMC Genom. 2010, 11, 496. [CrossRef]

25. Silver, N.; Best, S.; Jiang, J.; Thein, S.L. Selection of housekeeping genes for gene expression studies in human reticulocytes using real-time PCR. BMC Mol. Biol. 2006, 7, 33. [CrossRef]

26. Vandesompele, J.; De Preter, K.; Pattyn, F.; Poppe, B.; Van Roy, N.; De Paepe, A.; Speleman, F. Accurate normalization of real-time quantitative RT-PCR data by geometric averaging of multiple internal control genes. Genome Biol. 2002, 3, h31-h34. [CrossRef] [PubMed]

27. Andersen, C.L.; Jensen, J.L.; Ørntoft, T.F. Normalization of real-time quantitative reverse transcription-PCR data: A model-based variance estimation approach to identify genes suited for normalization, applied to bladder and colon cancer data sets. Cancer Res. 2014, 64, 5245-5250. [CrossRef] [PubMed]

28. Pfaffl, M.W.; Tichopad, A.; Prgomet, C.; Neuvians, T.P. Determination of stable housekeeping genes, differentially regulated target genes and sample integrity: BestKeeper-Excel-based tool using pair-wise correlations. Biotechnol. Lett. 2004, 26, 509-515. [CrossRef]

29. Livak, K.J.; Schmittgen, T.D. Analysis of relative gene expression data using real-time quantitative PCR and the $2^{-\Delta \Delta C T}$ method. Methods 2001, 25, 402-408. [CrossRef]

30. Zhou, Y.; Liu, S.; Yang, Z.; Yang, Y.; Liang, L.; Hu, L. CsCAT3, a catalase gene from Cucumis sativus, confers resistance to a variety of stresses to Escherichia coli. Biotechnol. Biotec. Eq. 2017, 31, 886-896. [CrossRef]

31. Smékalová, V.; Doskočilová, A.; Komis, G.; Šamaj, J. Crosstalk between secondary messengers, hormones and MAPK modules during abiotic stress signalling in plants. Biotechnol. Adv. 2014, 32, 2-11. [CrossRef]

32. Raja, V.; Majeed, U.; Kang, H.; Andrabicet, K.I.; Johna, R. Abiotic stress: Interplay between ROS, hormones and MAPKs. Environ. Exp. Bot. 2017, 137, 142-157. [CrossRef]

33. Liu, X.M.; Nguyen, X.C.; Kim, K.E.; Han, H.J.; Yoo, J.; Lee, K.; Kim, M.C.; Yun, D.J.; Chung, W.S. Phosphorylation of the zinc finger transcriptional regulator ZAT6 by MPK6 regulates Arabidopsis seed germination under salt and osmotic stress. Biochem. Bioph. Res. Co. 2013, 430, 1054-1059. [CrossRef]

34. Ye, J.; Jin, C.; Li, N.; Liu, M.; Fei, Z.; Dong, L.; Li, L.; Li, Z. Selection of suitable reference genes for qRT-PCR normalisation under different experimental conditions in Eucommia ulmoides Oliv. Sci. Rep. 2018, 8, 15043. [CrossRef]

35. Mafra, V.; Kubo, K.S.; Alves-Ferreira, M.; Ribeiro-Alves, M.; Stuart, M.R.; Boava, L.P.; Rodrigues, C.M.; Machado, M.A. Reference genes for accurate transcript normalization in citrus genotypes under different experimental conditions. PLoS ONE 2012, 7 , e31263. [CrossRef] [PubMed]

36. Niu, X.; Chen, M.; Huang, X.; Chen, H.; Tao, A.; Xu, J.; Qi, J. Reference gene selection for qRT-PCR normalization analysis in kenaf (Hibiscus cannabinus L.) under abiotic stress and Hormonal stimuli. Front. Plant Sci. 2017, 8, 771. [CrossRef] [PubMed]

37. Yang, Q.; Yin, J.; Li, G.; Qi, L.; Yang, F.; Wang, R.; Li, G. Reference gene selection for qRT-PCR in Caragana korshinskii Kom. under different stress conditions. Mol. Biol. Rep. 2014, 41, 2325-2334. [CrossRef] [PubMed] 
38. Chen, H.; Hu, B.; Zhao, L.; Shi, D.; Qin, Y. Differential expression analysis of reference genes in pineapple (Ananas comosus L.) during reproductive development and response to abiotic stress, hormonal stimuli. Trop. Plant Biol. 2019, 12, 67-77. [CrossRef]

39. Wang, B.; Duan, H.; Chong, P.; Su, S.; Shan, L.; Yi, D.; Wang, L.; Li, Y. Systematic selection and validation of suitable reference genes for quantitative real-time PCR normalization studies of gene expression in Nitraria tangutorum. Sci. Rep. 2020, $10,15891$. [CrossRef] [PubMed] 